\title{
Response of Grasses, Forbs, and Halfshrubs to Chemical Control of Chaparral in Central
}

Arizona

FLOYD W. POND

Range Conservationist, Rocky Mountain Forest and Range Experiment Station, ${ }^{1}$ Fort Collins, Colorado

Chaparral occupies about 6 million acres in Arizona and western New Mexico. The main body of the type begins near Silver City, New Mexico, and extends as a relatively narrow, discontinuous band across Arizona to Seligman.

Grazing by livestock and game is an important use of chaparral. Numerous grasses, forbs, and halfshrubs are present in the type. The amount and kind of understory varies with shrub density, climate, soil type, and past use. Fair amounts of grass are produced between the shrubs in some areas, and many shrubs are grazed, especially in winter. Where interspaces are essentially bare and palatable shrubs are scarce, forage production is low. In such areas, increases in forage might be expected if the unpalatable shrubs were killed. This study, begun in 1954 on the Sierra Ancha Experimental Forest, reveals some effects of killing shrubs and trees in the chaparral on production and cover of associated grasses, forbs, and halfshrubs.

Chaparral commonly occurs on the broken, rough slopes of the mountainous masses just south of the Mogollon Rim. The type extends into the edge of the pine at higher elevations $(6,000+$ feet) and mingles with desertshrub species at lower elevations (3,500 feet). Soils, generally poorly developed, are of several

\footnotetext{
${ }^{1}$ Forest Service, U. S. Department of Agriculture, with headquarters at Fort Collins, Colorado, in cooperation with Colorado State University. Research reported was conducted in cooperation with Arizona State University at Tempe, Arizona.
}

parent materials - granite, diabase, quartzite, schist, and basalt. Rainfall, generally varying with elevation, ranges from 14 to 25 inches.

The type is usually dominated by one or two shrub species, although mixtures of many species are found on some sites. Structure of the flora and dominance are generally influenced by differences in soils, slope, elevation, and precipitation. More than 50 shrub species have been found in the type, but the usual dominant is shrub live oak (Quercus turbinella). Other common species are skunkbush sumac (Rhus trilobata), sugar sumac $(R$. ovata) and desert ceanothus (Ceanothus greggii). Species that often are dominant locally include hairy mountainmahogany (Cercocarpus brevifolius), birchleaf mountainmahogany (C. betuloides), pointleaf manzanita (Arctostaphylos pungens) and Pringle manzanita (A. pringlei). Wright silktassel (Garrya wrightii) and hollyleaf buckthorn (Rhamnus crocea), though common, are important mainly because of animal preference.

\section{Literature Review}

Little work has been done in the chaparral of Arizona, on the effect removing the shrub overstory has on native grasses and halfshrubs. Removing overstory trees and shrubs, however, has resulted in increased understory growth in other vegetation types. Several workers, among whom are Mueggler and Blaisdell (1958), Blaisdell (1953), Pechanec and Robertson (1944), and Hyder (1954), have found that killing big sagebrush overstory releases understory vegetation and results in two- to five-fold increases in usable forage. Similar results are reported from other shrubby or weed-tree types: mesquite (Parker, 1943); juniper (Arnold and Schroeder, 1955) and post oak (Koshi et al, 1954). In the California chaparral, a type somewhat similar to that in Arizona, Biswell (1954), Love and Jones (1947), and Burcham (1959), are among those who advocate conversion of chaparral to grassland to increase forage production and watershed efficiency.

\section{History of the Study Areas}

The study was made on four small watersheds (9.07 to 19.52 acres in size) called the Natural Drainages, located on the Sierra Ancha Experimental Forest about 40 miles north of Globe, Arizona. The four watersheds arc designated $\mathrm{A}, \mathrm{B}, \mathrm{C}$, and $\mathrm{D}$ and lie side by side facing east (Figure 1). Slopes average 15 to 25 percent, and elevations from 4,525 to 4,970 feet. Annual rainfall averages about 20 inches; 65 percent falls October through May, and 35 percent June through September.

Two distinct soils are present. Soil on the upper slopes was derived from diabase rock; it is deep and sandy. On the lower slopes is a shallow, quartzite-derived soil, heavier in texture than the diabase soil. Vegetation on the diabase soil consists primarily of shrubs and halfshrubs. Though shrubs are also dominant on the quartzite soil, islands of grass are common there.

The Natural Drainages were closed to livestock grazing from 1934 to 1938. From 1939 to 1954, the effect of grazing on water production was studied on the watersheds. Each fall cattle grazed about 80 percent of the grass on the more accessible slopes on Drainage A and about 40 percent on Drainage D. Areas of dense brush and steep topog- 


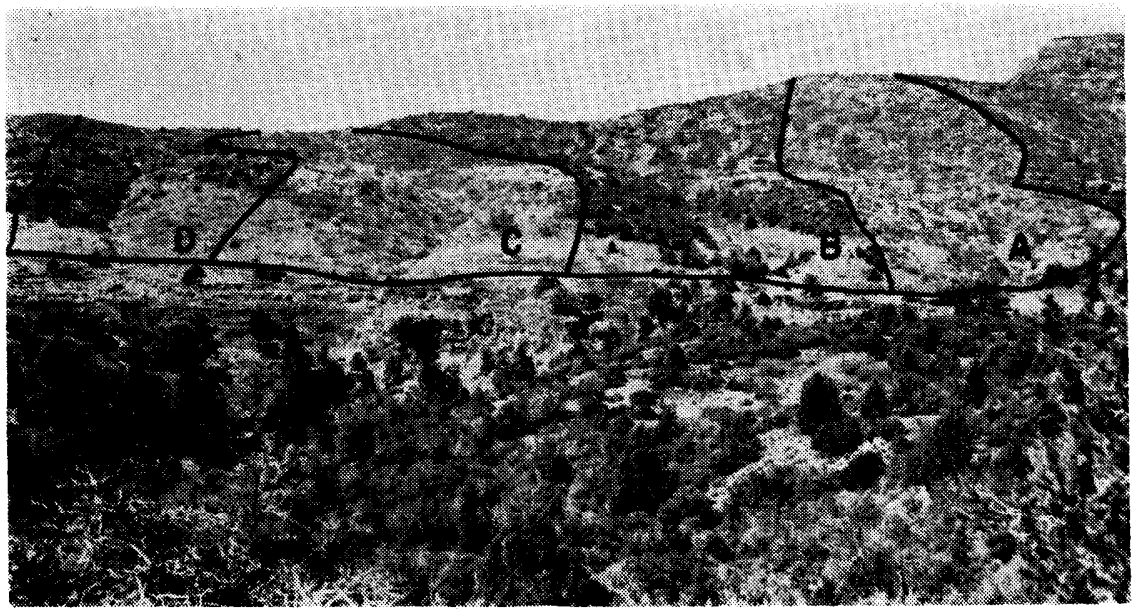

Figure 1. The four Natural Drainages on the Sierra Ancha Experimental Forest 4 years after initial chemical treatment of shrubs on Drainages $\mathrm{A}$ and $\mathrm{C}$.

raphy were seldom grazed on either watershed. Drainages B and $C$ were held as ungrazed check areas. From 1955 until the end of the study in 1959, livestock were again excluded from all watersheds.

\section{Methods}

To determine the response of understory vegetation to chemical control of chaparral, all shrubs and trees on Drainages $\mathrm{A}$ and $\mathrm{C}$ were sprayed with herbicides while Drainages $B$ and $\mathrm{D}$ were held as check areas.

During the summer of 1954 , the basal 6 inches of each living shrub and tree on Drainage $C$ was sprayed with a 6.6 percent solution of 2,4-D and 2,4,5-T in diesel oil until the outer bark was saturated. Halfshrubs were not sprayed. Though the first treatment killed most of the plants sprayed, surviving shrubs on Drainage $\mathrm{C}$ were resprayed in 1956 and 1958. Trees and shrubs on Drainage A were sprayed in similar manner in 1955 and resprayed in 1957.

Measurement of plant cover.To facilitate sampling, each drainage was type-mapped according to dominant vegetation, aspect, and soil derivation. Although 8 types were represented, the present study is concerned only with the 3 types that had a shrub overstory:
Shrub, south-facing slope, quartzite soil

Shrub, north-facing slope, quartzite soil

Shrub, east-facing slope, diabase soil

In 1950 , ten 40 -foot line transects were randomly located in each vegetation type in each drainage. Crown- and basal-intercepts of plants along those transects were recorded in August 1954, 1957, and 1959 in the manner described by Canfield (1942).

Measurement of herbage production. - Estimates of herbage production were made in 1959. Five mechanically spaced 9.6square-foot plots were located near 5 of the 10 line transects in each type. Current production of grasses was determined by the weight-estimate method (Pechanec and Pickford, 1937). One of the five plots on each transect, randomly chosen, was clipped and the herbage weighed as part of a double sampling procedure (Wilm et al. 1944).

Forbs were not estimated because the work was done in November after most forb herbage had dried, broken up, and blown away. All growth of halfshrubs was estimated because old growth could not be distinguished readily from new growth.

\section{Changes in Vegetative Cover}

Grasses. - In 1954, the basal cover of all grasses on proposed treatment areas of quartzite soils was almost the same as that on check areas (Figure 2). In 1957 and 1959, grass cover on treated areas was about three times that on check areas. Increases on north and south slopes were comparable. Side-oats grama (Bouteloua curtipendula) alone was responsible for much of the basal cover change following treatment, although other grasses also contributed. No significant changes in grass cover were detected on sprayed or unsprayed areas of diabase soils during the entire study period. Any small changes that may have occurred were obscured by variation in cover.

These data suggest that grass cover, especially that of sideoats grama, may increase rapidly following shrub control on quartzite soils, but little or no change may be expected on diabase soils. The fact that grassy openings are common on the shallow, clayey quartzite soils but are infrequent on the deep, sandy diabase soils tends to support this observation.

Halfshrubs. - Crown cover of halfshrubs increased substantially on both soils following chemical control of shrubs. The greatest actual increase, however, was on diabase soils (Figure 2). The principal species were Wright eriogonum (Eriogonum wrightii), rough menodora (Menodora scabra) and two species of Lotus, shrubby deervetch (L. rigidus) and Wright deervetch ( $L$. wrightii). No apprecyable change in cover occurred on unsprayed areas during the study. The significant increase of halfshrubs following shrub kill indicates that both soils are well adapted for growing these plants.

Forbs.-Crown cover of forbs was greater on the diabase than the quartzite soils. Forbs apparently increased on all treated areas between 1954 and 1959 
(Figure 2) although these differences were not significant.

\section{Production Increases}

Grasses.-Grass production in 1959 was over twice as great on quartzite soils on which shrubs had been controlled as on comparable check areas (Figure 3). This significant difference was due to increased production of side-oats grama on the sprayed areas. The response of grass production to shrub control was similar on north and south aspects.

On diabase soils, grass produc-
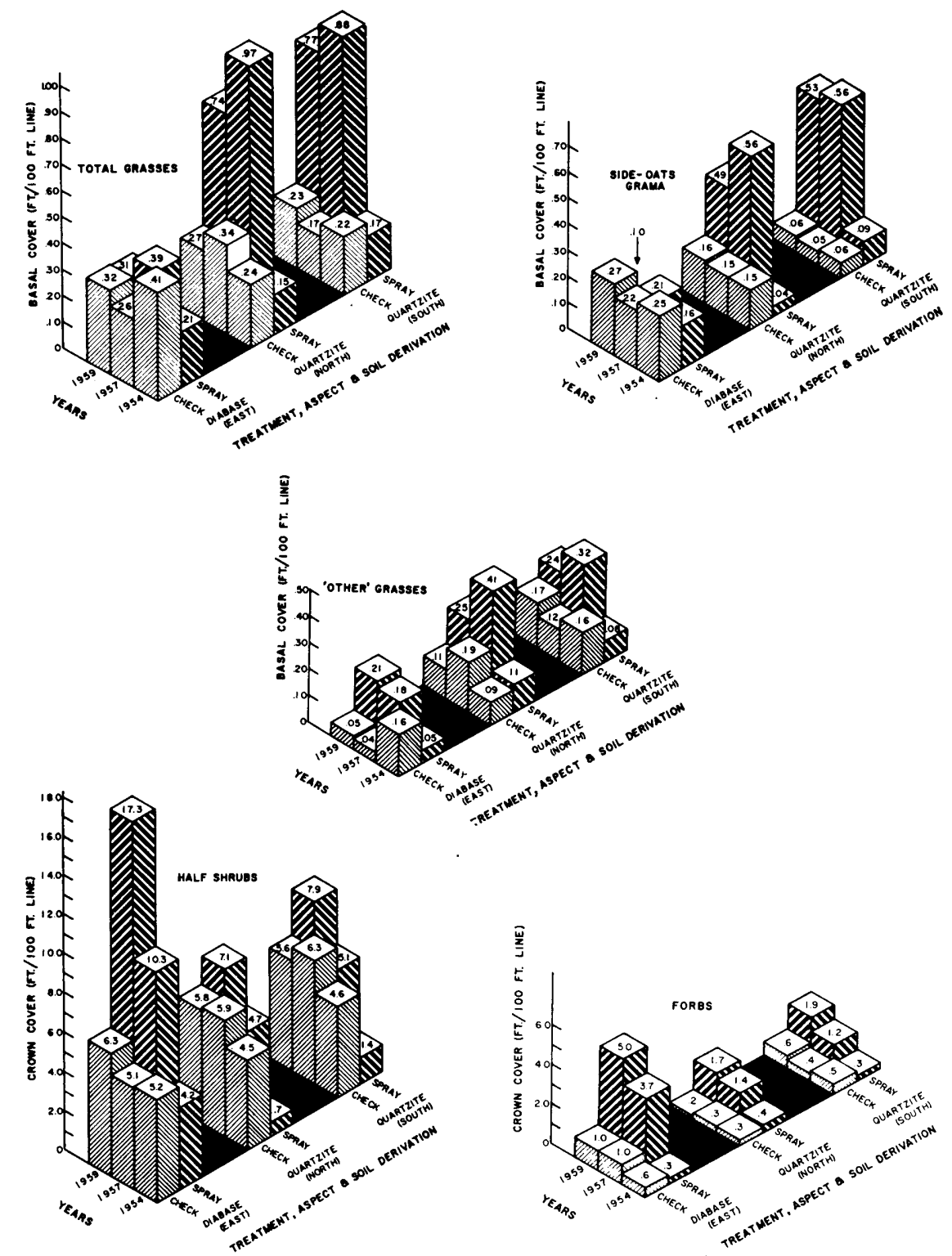

Figure 2. Basal cover of grasses, and crown cover of forbs and halfshrubs in 1954 before shrubs were controlled, and in 1957 and 1959 after control. production of halfshrubs on sprayed areas was little different from that on unsprayed areas in 1959 (Figure 3). Indicated differences were not significant.

In contrast, on diabase soil, production of halfshrubs on sprayed areas averaged 274 pounds per acre, 13 times the production on check areas. This was nearly three times the production on quartzite soil.

If a good stand of grass is desired, control of halfshrubs may be necessary, even though some halfshrubs may provide forage for deer and livestock. Cover of half shrubs was still increasing at the end of the study wherever shrubs had been controlled. Like the shrubs, they probably compete with the grasses.

In practice, halfshrubs will likely be controlled along with shrubs. Basal application of chemicals to shrubs is not economically feasible, as costs are well over 100 dollars per acre. Chemical control of shrubs on large areas will likely be done with airplanes or helicopters; chemicals that kill shrubs will probably kill most halfshrubs in the chaparral.

\section{Summary}

Responses of grasses, forbs, and halfshrubs following chemical control of chaparral were ob-

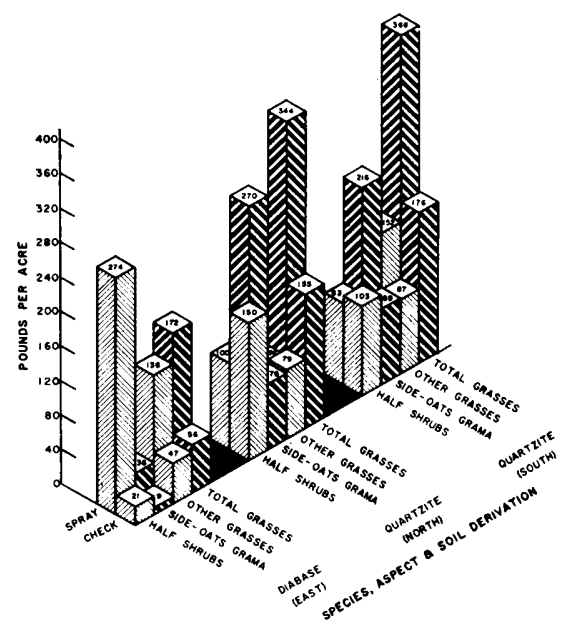

Figure 3. Production of grasses and halfshrubs in 1959, 5 years after initial chemical treatment to control shrubs. 
served from 1954 to 1959 on the Sierra Ancha Experimental Forest in central Arizona. Study areas were classified and results were presented according to dominant vegetation, aspect, and soil origin.

Soils derived from quartzite were shallow and contained considerable amounts of clay. Islands of grass were present in the chaparral on this soil before treatment. Following shrub control with herbicides, the cover of all understory vegetation on quartzite soil increased, but increase in grass cover was quickest and most spectacular. Halfshrubs and forbs increased less rapidly but continuously. Increase in grass production was also greater on this soil.

Soils derived from diabase were deep and sandy. They supported no islands of grass in the chaparral. Here, halfshrubs increased greatly in cover and production following control of overstory shrubs. Grasses showed little if any response, while forbs increased in cover somewhat more than on quartzite soils.
These findings indicate that chaparral-control sites for increased grass production should be selected carefully. Certain soils may not favor grass growth, and other plants not killed by herbicides may become dominant.

\section{LITERATURE CITED}

ARNOLD, Joseph F. AND William L. Schroeder. 1955. Juniper control increases forage production on the Fort Apache Indian Reservation. U. S. Forest Serv. Rocky Mountain Forest and Range Expt. Sta. Sta. Paper 18. $35 \mathrm{pp}$.

Biswell, H. H. 1954. The brush control problem in California. Jour. Range Mangt. 7:57-62.

Blaisdell, James P. 1953. Ecological effects of planned burning of sagebrush-grass ranges on the Upper Snake River plains. U.S. Dept. Agr. Tech. Bul. 1075. 39 pp.

Burcham, L. T. 1959. Planned burning as a management practice for California wildlands. Calif. Div. Forestry, Sacramento, Calif. 21 pp.

Canfield, R. H. 1942. Sampling ranges by the line interception method. U. S. Forest Serv. Southwestern Forest and Range Expt. Sta. Res. Report 4. 25 pp.

Hyder, Donald N. 1954. Spray to control big sagebrush. Ore. Agr. Expt. Sta. Bul. 538. 12 pp.
Koshi, Paul T., Robert A. Darrow, and Wayne G. McCully. 1954. Forage production in oak woodland as influenced by removal of tree cover. Texas Agr. Expt. Sta. Prog. Rpt. 1661. 4 pp.

Love, R. M. ANd BurLe J. Jones. 1947. Improving California brush ranges. Calif. Agr. Expt. Sta. Cir. 371. 39 pp. (revised 1952)

Mueggler, Walter F. and James P. BLAISDELL. 1958. Effects on associated species of burning, rotobeating, spraying, and railing sagebrush. Jour. Range Mangt. 11:6166.

Parker, Kenneth W. 1943. Control of mesquite on Southwestern ranges. U. S. Dept. Agr. Leaflet 234. $8 \mathrm{pp}$.

Pechanec, Joseph F. and G. D. PickFORD. 1937. A weight estimate method for the determination of range or pasture production. Jour. Amer. Soc. Agron. 29: 894-904.

Pechanec, Joseph F., A. Perry PlumMER, JOSEPH H. ROBERTSON, and others. 1944. Eradication of big sagebrush (Artemisia tridentata). U. S. Forest Serv., Intermountain Forest and Range Expt. Sta. Res. Paper 10. $23 \mathrm{pp}$.

Wilm, H. G., David F. Costello, AND G. E. KLIPPLE. 1944. Estimating forage yield by the double-sampling method. Jour. Amer. Soc. Agron. 36: 194-203. 